\title{
Além das cenas do crime: o fantasma de Tenório Jr. em meio às dissonâncias e disputas na historiografia do jazz brasileiro (1964-1976)
}

Beyond the scenes of crime: the ghost of Tenório Jr. amidst the dissonances and disputes in the historiography of Brazilian jazz (1964-1976)

Renan Branco Ruiz ${ }^{1}$ Universidade Estadual Paulista (UNESP) renan.ruiz@unesp.br https:/lorcid.org/0000-0002-0778-8895

Antonio Carlos Araújo Ribeiro Júnior ${ }^{2}$ Universidade Federal do Maranhão (UFMA) antonio_arir@hotmail.com https://orcid.org/0000-0002-0971-4339 


\section{Resumo}

Inspirados no paradigma indiciário (GINZBURG, 2007) e no método biográfico (BOURDIEU, 2001), analisamos os usos e abusos da história do pianista Tenório Jr. no interior da memória e da historiografia sobre o jazz brasileiro dos anos 1960-1970. Morto em 1976 em plena ditadura argentina, a figura do músico foi acionada como símbolo da condição do jazz nacional naquele período. Cotejamos, assim, a vida e os discursos sobre Tenório, destacando, por fim, os desmembramentos históricos do instrumental brasileiro. Chegamos ao entendimento de que a trajetória do músico foi apropriada para fundamentar leituras distintas sobre a relação entre canção e música instrumental, gerando posições estético-ideológicas conflitantes. Fundamentados em dados empíricos, problematizamos essas narrativas e percebemos que as nuances da memória trágica de Tenório dão indícios, mas não determinam os rumos que o jazz e a música instrumental brasileira tomaram nos anos 70. Assim, concluímos que apesar dos traumas sofridos, esses estilos não "morreram" nos porões da indústria fonográfica. Antes, resistiram e se reinventaram.

Palavras-chave: memória musical; sambajazz; jazz/instrumental brasileiro; ditadura militar; América Latina

\section{Abstract}

Inspired by the evidentiary paradigm (GINZBURG, 2007) and the biographical method (BOURDIEU, 2001), we analyze the uses and abuses of the history of pianist Tenório Jr. within the memory and the historiography of Brazilian jazz from the 1960s to 1970s. Murdered in 1976 during the Argentine dictatorship, the figure of the musician was used as a symbol of the national jazz condition in that period. Thus, we compare the life and discourses about Tenório, finally highlighting the historical dismemberments of the Brazilian instrumental. We came to the understanding that the musician's trajectory was appropriate to support different readings about the relationship between song and instrumental music, producing discrepant aesthetic-ideological positions. Based on empirical data, we problematize these narratives and realize that the nuances of Tenório's tragic memory provide clues but do not determine the directions that jazz and Brazilian instrumental music took in the 70s. Thus, we conclude that despite the traumas suffered, these styles did not "die" in the basements of the recording industry. On the contrary, they resisted and reinvented themselves.

Key-words: musical memory; sambajazz; brazilian jazz/instrumental; dictatorship; Latin America

\footnotetext{
1 Doutorando e mestre em História e Cultura Social pela Faculdade de Ciências Humanas e Sociais da Universidade Estadual Paulista (UNESP). Membro do GECU (Grupo de Estudos Culturais da UNESP) e do GEJAZZBR (Grupo de Estudos Jazz no Brasil).

2 Graduado em História pela Universidade Estadual do Maranhão. Mestre em Cultura e Sociedade pela Universidade Federal do Maranhão (PGCULT) e pós-graduando em História e Cultura Afro-brasileira pela FACUMINAS. Integrante do GEJAZZBR (Grupo de Estudos do Jazz no Brasil) e do GPMUSI (Grupo de Estudos em Práticas Musicais no Maranhão).
} 


\section{Introduzindo o caso: pistas e questões}

Todo está cargado en la memoria: arma de la vida y de la historia.

La Memoria - Léo Gieco.

Duas canções do disco Calabar - O Elogio da Traição (Phonogram/Philips, 1973) de Chico Buarque tornaram-se instrumentais por causa da violenta censura que assolou o país com a promulgação do Al-5. "Vence na vida quem diz sim" e "Ana de Amsterdam" tiveram suas letras vetadas pelos censores, que, talvez, não atentassem para o fato de que, desta forma, só reforçavam o teor subversivo das composições, atraindo a atenção do público contrário ao regime instaurado em 1964. Se, por um lado, a atitude sugeria que para a censura todo o engajamento e resistência das músicas residiam apenas nos versos das canções, direcionando as atenções só para os cantores e compositores, ${ }^{3}$ por outro lado, o próprio LP silenciava acerca dos músicos que participaram da gravação. A capa do disco só indica o compositor e o intérprete: Chico e Ruy Guerra, respectivamente. Supondo que os músicos foram os mesmos que participaram da trilha sonora da peça Calabar (também censurada), surgem os nomes de Maurício Mendonça no contrabaixo, João Palma na bateria, Danilo e Dorival Caymmi nos violões e, por último, mas não menos importante, Francisco Tenório Jr. no piano.

Além de ilustrar o principal problema que analisaremos neste artigo (o possível apagamento dos instrumentistas e de suas produções no período da ditadura civil-militar), destacamos a presença do músico Tenório Jr., que entendemos ser fundamental para esta discussão. Assassinado em Buenos Aires em 1976 pelos aparelhos repressivos da ditadura argentina com o aval do Estado brasileiro, o interesse em Tenório Jr. se justifica pelo fato de a tragédia que o acometeu (um caso em aberto até hoje, pois jamais esclarecido) ter simbolizado, como mostraremos, peça-chave nos conflitos narrativos acerca da formatação da música instrumental popular brasileira e do jazz no período ditatorial.

Uma fonte primordial para o nosso estudo é o livro O crime contra Tenório: saga e martírio de um gênio do piano brasileiro, publicado em 1997 e de autoria do ex-guitarrista do Som Imaginário, Frederico Mendonça de Oliveira, conhecido como Fredera.

Valendo-se do depoimento de um ex-integrante do Serviço de Inteligência da Marinha, a obra fornece maiores detalhes acerca da tragédia de Tenório e de sua repercussão. Além disso, defende uma tese que visamos problematizar: o vínculo entre o

3 Breve esclarecimento: isso não deve levar a crer que a música instrumental não foi prejudicada e não passou por censura também, como foi o caso do grupo formado apenas por negros, Oliveira e seus Black Boys, que em 64 entrou na mira do DOPS por ter sido acusado de deturpar o hino nacional, inserindo arranjos de twist (BARROS, 2012). Por outro lado, como indica uma matéria da Época (07/03/2014), documentos do Arquivo Nacional de Brasília mostram que houve uma dúbia aliança entre as entidades dos músicos e a Divisão de Censura da Polícia Federal. Em nome da proteção dos direitos autorais ou de classe, a Sicam (Sociedade Independente de Compositores e Autores Musicais), o SDDA (Serviço de Defesa do Direito Autoral), o Ecad (Escritório Central de Arrecadação) e a OMB (Ordem dos Músicos do Brasil) protagonizaram junto à DCDP (Divisão de Censura e Diversões Públicas) intervenções truculentas sobre os próprios músicos. Cf. Como sindicatos de artistas mantiveram uma relação ambígua com a Censura na ditadura - ÉPOCA | Ideias (globo.com). À propósito, como se desprende dos escritos de Souza Neto (2014), marco simbólico dessas contradições e perseguições foi o aparelhamento, logo após o golpe militar, do principal órgão regulador da profissão de músico no país, a OMB. Sob o pretexto falacioso de combate à intervenção comunista na música, a Ordem recebeu poderes policiais, tornando-se "instrumento de censura, geração de desigualdades, assimetrias e exclusão de músicos do mercado de trabalho" (SOUZA NETO, 2014, p. 02). 
ofuscamento da memória de Tenório e o suposto boicote e apagamento da música instrumental/jazz brasileiro.

Isto posto, questionamos: até que ponto e em que medida a trajetória do pianista nos revela acerca do lugar da música instrumental jazzística no Brasil entre os anos 60 e 70? Teria mesmo havido uma articulação em favor do esquecimento de Tenório Jr., e, por associação, de outros instrumentistas? Que interesses rondariam as narrativas que se valem da memória do músico, e mais fortemente de sua morte, nesse debate?

Diante dessas questões, nos interessa ao mesmo tempo averiguar o tratamento dado à memória de Tenório e problematizar os usos e abusos dessa memória, focados, sobretudo, na sua imagem-símbolo (o que esta engloba e o que deixa escapar, evidentemente). Nesse sentido, estamos cientes do risco de incorrer numa "ilusão retórica" (BOURDIEU, 2011, p. 76), selecionando fatos notáveis da vida do músico, para fins de coerência narrativa. Isso é possível por conta de nossa opção em destacar a importância do instrumentista e de sua produção para o período estudado, como forma de localizar e perceber a trajetória do jazz brasileiro. Entretanto, estabelecendo um jogo dialético entre recortes da vida do músico e o contexto em que estava inserido; interrogando criticamente discursos e representações com base nas fontes, e consultando dados empíricos acerca da condição do instrumental, acreditamos poder evitar romantizações. Enquanto estratégia narrativa, a biografia do músico nos servirá, assim, como fio condutor, e não como um fim em si mesmo; o que recairia na mera compilação de informações pessoais sobre ele.

Em outros termos, embora não intente esmiuçar a vida de Tenório, essa opção visa estimular também uma retomada da figura do pianista; figura essa que, se comparada a de outros artistas, não é satisfatoriamente tratada pela historiografia, sem que haja teses ou dissertações que busquem retrabalhar sua vida (ou fenômenos que a cercam), tornando-a uma simples nota de rodapé em muitos trabalhos acadêmicos ${ }^{4}$. Dessa forma, não obstante nossa articulação teórica-metodológica não se prenda estritamente à trilha biográfica, utilizaremos documentos e bibliografia sobre o caso de Tenório Jr., como fontes a partir das quais pinçaremos episódios/pistas que nos servirão no cruzamento de informações para o debate historiográfico maior: este, sim, centrado no lugar do jazz brasileiro no período delimitado. Inspirados pelas reflexões metodológicas de Ginzburg (2007, p. 276 - 277) examinaremos o objeto a partir da interação entre diferentes escalas de análise: alguns pormenores da carreira de Tenório e da fatalidade ocorrida na Argentina, articulados com cenário mais abrangente do jazz brasileiro e da música popular instrumental.

Dessa forma, nosso recorte visa abarcar o momento de explosão do sambajazz, momento que deu o fôlego para o nascimento do jazz brasileiro e que teve participação fundamental de Tenório Jr. com seu disco Embalo (1964), e vai até o ano de sua morte (1976), momento de intensas transformações na produção instrumental e quando se

\footnotetext{
4 Contribuição interessante, convém citar, foi a de Fiuza (2006), cujo artigo retrilha a trajetória de Tenório Jr. e traz algumas informações importantes, sem, no entanto, atentar para os silêncios impostos à memória do músico, nem problematizar a situação dos instrumentistas e de sua produção em meio à ditadura.
} 
inicia um processo de construção do lugar social da memória do músico.

\section{Antes do terrível revés: Tenório Jr. e a criação do sambajazz}

Completou-se 45 anos desde o desaparecimento e morte de Francisco Cerqueira Tenório Jr. Nascido em Laranjeiras, Rio de Janeiro, em 04 de julho de 1941, e filho de Alcinda Lourenço Cerqueira e Francisco Tenório Cerqueira, se vivo, hoje o músico estaria completando 81 anos. Um tiro sem misericórdia, porém, tirou-lhe a vida antes que chegasse aos 36 . Sobre essa fatalidade, nos deteremos mais atenciosamente no próximo tópico.

Em termos biográficos, os dados sobre a formação educacional de Tenório incluem que cursou a Faculdade Nacional de Medicina enquanto se dedicava ao piano, mas não informam sobre sua formação musical, restando supor que pelas condições econômicas da família tomou aulas particulares e tinha instrumento próprio. Não se pode descartar a hipótese de ser autodidata, como muitos músicos vinculados ao sambajazz.

Aliás, dentre as muitas ações e empreitadas musicais de Tenório, ser um expoente do sambajazz foi uma delas, sendo figura central para compreender os rumos dessa sonoridade durante a década de 1960. O pianista manteve intenso trânsito pela comunidade musical carioca, acompanhando diversos cantores e instrumentistas. Porém, gravou e lançou apenas um disco solo, Embalo (1964, RGE). Tal álbum pode ser compreendido, de certa forma, como uma espécie de "manifesto sambajazz", reorganizando o material musical pautado nas combinações entre as músicas populares do Brasil e o jazz.

Apesar das muitas problemáticas em torno da narrativa reincidente que fixa a bossa como marco inicial de modernização da música nacional, no segundo pós-guerra, o sambajazz marca uma nova relação entre jazz e música brasileira do final dos anos 1950 e início dos 1960. Tratava-se de uma nova concepção instrumental que florescia nesse período, produzindo diversas possibilidades que gradativamente se distanciavam do formato bossa nova-canção. Além de "sambajazz", essas composições instrumentais foram denominadas de várias maneiras: "sambalanço", "jazz samba", "hard bossa", "bossa-jazz", "sambop", "bossa nova instrumental", "samba moderno", "Música Popular Moderna" (MPM), termos que se confundiam. Apesar das devidas distinções entre as práticas, utilizaremos a expressão sambajazz para representar as formas de nomeação relacionadas ao universo da música instrumental desse período bossanovista.

Em seu artigo no Correio da Manhã (25/10/1964), intitulado "Pequena História do Samba-Jazz", o crítico francês Robert Celerier defendia que o primeiro disco cuja sonoridade se vinculava a esse movimento musical foi o Turma da Gafieira (Musidisc, 1957), contando com músicos como Cipó e Zé Bodega (sax), Edison Machado (bateria), Altamiro Carrilho (flauta), Maurílio Santos (trompete), Nestor Campos (guitarra), Paulinho e Britinho (piano).

Posteriormente, no que se refere a organização dos instrumentos, o sambajazz se caracterizaria pela formação de piano, baixo e bateria, reconhecida como "pianos-trio", adicionando eventualmente outros instrumentos como violão, percussão e instrumentos de sopro, dependendo das possibilidades e composições de cada artista. Dentre al- 
guns discos e conjuntos representativos, podemos citar: Zimbo Trio, Tamba Trio, Edison Machado, Milton Banana Trio, Rio 65 Trio, Paulo Moura, Embalo Trio, Grupo Bossa Três, Os Cobras, Meirelles e os Copa 5, Hector Costita Sexteto entre muitos outros, com alta atividade musical, principalmente, entre os anos 1962-1966 (ALEXANDRE, 2009, p. 52).

Diferente da bossa nova, que tem seu lugar extremamente consolidado na imprensa e na bibliografia acadêmica sobre a música brasileira, essas manifestações instrumentais - que foram tão atuantes quanto a canção no mesmo período - foram postergadas por parte da historiografia musical, ainda hesitante quanto a esse objeto de pesquisa. Visando mitigar esse problema, nos últimos anos, novas pesquisas vêm tentando mapear e reconstruir esse cenário de forma mais abrangente. Além de Saraiva (2007) e França (2015), Mongiovi (2017, p. 86) e Gomes (2010, p. 82), por exemplo, destacam a presença das propostas relacionadas ao universo instrumental bossanovístico desde, pelo menos, 1952. Na esteira dessas produções, informamos que a expansão com o formato instrumental baseado nos pianos-trio ilustrava um momento de consciência e expectativa, por parte de seus praticantes, sobre a atuação nos rumos da música brasileira. Conforme demonstra a capa do LP Meu fraco é café forte (Philips, 1965), da banda Rio 65 Trio, formada por Edison Machado (bateria), Sérgio Barrozo (contrabaixo) e Dom Salvador (piano):

É agora que a música popular brasileira atinge sua maturidade. Há sucesso enorme por toda parte. Músicas e músicos brasileiros desbravam os mais difíceis mercados, as mais inacessíveis regiões do mundo. É o despertar musical do Brasil. Foram necessários quatro séculos de inspiração e talento para criar esta força única e indestrutível. Pela primeira vez na história da música popular de todo o mundo, um país desponta em pleno século XX com tamanho potencial de sucesso e - o que é importante - com música de ritmo, inspiração e talento inteiramente nacionais. E é aqui que entra o papel importante prestado pelo músico brasileiro. Graças a ele, a nossa MPM (sic) é hoje, sinônimo de música inteligente, porém sem deixar de ser popular.

A possibilidade de alterar os rumos da música brasileira pelo viés instrumental parece ter incentivado um ímpeto renovador buscado pelos instrumentistas. Tanto que os pianos-trio se espalharam não somente pelo Beco das Garrafas ${ }^{5}$, no Rio de Janeiro, mas também por diversos bares, casas de show e bairros de São Paulo. Apontando a relevância dos trios instrumentais enquanto potencializadores de um momento de grande criatividade na música brasileira, Campos (2014, p. 30) ressalta que:

Esse período foi fundamental para o desenvolvimento de uma linguagem musical muito específica na música brasileira. Com influências da música norte-americana, principalmente na maneira de improvisar, e utilizando como repertório canções brasileiras da bossa-nova e do samba, os músicos deste período atuaram bastante, tanto no cenário carioca, quanto no paulista.

5 Espaço boêmio considerado o principal palco e aglutinador dos trios instrumentais. Localizado numa rua sem saída no bairro de Copacabana, contava com quatro boates Little Club, Bottle's, Baccará e Ma Griffe, criadas no final dos anos 1950. 
Dessa forma, é possível salientar a importância dos instrumentistas e da música instrumental jazzística para a estruturação de um novo mercado de música no geral, mais abrangente, também relacionado ao contexto da bossa nova enquanto uma das principais expressões da música cantada no sudeste do país. Ou seja, a música popular instrumental e o sambajazz foram responsáveis por auxiliar na estruturação de um novo mercado musical e criativo também na canção nacional durante os anos 1950 e 1960.

Outro aspecto precisa ser reiterado: é a partir do sambajazz que a música brasileira passa a ter um contato próximo com as propostas de improvisação, sendo cada vez mais praticada pelos instrumentistas do período. Isso ocorreu, também, devido à incorporação das jam sessions pelos músicos do sudeste do país em meados dos anos 1950 e início dos anos 1960; diversas delas realizadas no Beco das Garrafas (SARAIVA, 2007, p. 37). Valendo-se do vocabulário rítmico do bebop/hard bop somado à base de samba e de harmonias impressionistas, o formato de bateria-piano-baixo se deslocava do clima intimista de violão e voz, tão marcantes da bossa nova, que, ao contrário do sambajazz, evitava ou regulava exibições instrumentais. Este é um elemento determinante de diferenciação entre ambos: o improviso enquanto característica central.

Portanto, ao criar espaços de improviso instrumental, o sambajazz forjou um universo musical mais livre e artesanal, destacando os instrumentistas como compositores/criadores. Mesmo que tenham surgido de forma concomitante e se retroalimentado em vários níveis, a bossa-nova (canção) e o sambajazz (enquanto universo instrumental) representam propostas, sonoridades e projetos musicais bastante distintos. Não por acaso, muitos músicos e bandas acompanhavam cantores como parte de seu trabalho e meio de sobrevivência, mas tinham no sambajazz uma forma de lançar seus trabalhos autorais. É exatamente esse o caso de Tenório.

Tendo iniciado em 1962 nas jams sessions da Little Club, Tenorinho, como era conhecido na época, foi um dos nomes que seriam catapultados pelo Beco das Garrafas, verdadeiro laboratório de experimentações instrumentais. Em 1963, já subia aos palcos de festivais internacionais para representar o Brasil, como o Jazz en La Costa, no Mar del Plata. De volta ao solo brasileiro, tocou no Manhattan Club acompanhando a cantora Leny Andrade e na boate Au Bon Gourmet. Gravou álbuns importantíssimos para a música brasileira como: É Samba Novo (CBS, 1964) com Edison Machado; A Arte Maior (Polydor, 1964) com Leny Andrade; Vagamente (RGE, 1964) de Wanda Sá; Desenhos (FORMA, 1966) de Victor Assis Brasil; O LP (RCA, 1964), Lição de Balanço (RGE, 1964), do conjunto Os Cobras formado por Ed Maciel, Zé Bodega, Copinha, Dom Um Romão, Rubens Bassini, Cipó, Humberto Garin, Jorginho Dálgio e Julinho Barbosa.

Além dos nomes supracitados, o pianista gravou com diversos artistas como Chico Buarque, Gal Costa, Lô Borges, Milton Nascimento, Beto Guedes, Nelson Angelo, Joyce, Edu Lobo, entre outros. Mas foi no universo da música instrumental que Tenório encontrou uma saída para gravar, no auge de seus 21 anos de idade, seu único trabalho "solo" como líder do grupo e das composições: o LP Embalo, justamente um dos marcos do sambajazz.

Como destaca Ruy Castro (2017), a ideia do disco surgiu de um convite feito pelos diretores da RGE José Scatena e Benil Santos, que permitiram a Tenório escolher o 
engenheiro de som, decidir livremente sobre os arranjos, a escolha dos músicos e até sobre a capa do LP, o que ilustra o prestígio dispensado ao músico e à sonoridade do sambajazz. Tal fato indica que havia significativo potencial mercadológico em torno do sambajazz, a ponto de as gravadoras investirem nessa nova produção, visando, evidentemente, o público fã de jazz e samba, ávido por novidades sonoras num período de difusão do rock. É de se supor que havia então boas expectativas quanto à aceitação do disco Embalo.

Gravado entre fevereiro e março de 1964, e composto por onze músicas, o LP abre com a faixa homônima "Embalo" (composição de Tenório com arranjos do saxofonista Paulo Moura). Há ainda "Inútil Paisagem" (Aloysio de Oliveira/Antonio Carlos Jobim); "Clouds" (Durval Ferreira/Maurício Einhorn); "Consolação" (Baden Powell/Vinícius de Moraes); "Sambinha” (Bud Shank); "Fim de Semana” (Johnny Alf); "Carnaval sem Assunto" (Zezinho Alves), fora outras composições do próprio pianista: "Estou nessa agora", "Samadhi", "Néctar" e, por fim, "Nebulosa”. O registro contou com um elenco de músicos de peso. Entre eles: Ed Maciel, Milton Banana, Celso Brando, Hector Costita, Rubens Bassini, Sérgio Barrozo, J. T. Meirelles e Ronnie Mesquita. Especificamente sobre a composição “Embalo", Rodrigues (2020, p. 139-140) comenta:

\begin{abstract}
Trata-se de um samba-jazz arranjado pelo saxofonista Paulo Moura, no qual se vê a influência do jazz em frases bebop, e a forte personalidade de Milton Banana, que toca um samba aberto, mais livre do que o samba tradicional. Milton, assim como outros bateristas do samba jazz, resumem, na bateria, a concepção orquestral múltipla de instrumentos percussivos que já estavam presentes nas rodas de samba. Essa presença rítmica, não só do baterista Milton Banana, mas também do próprio Tenório e dos baixistas que participam do disco, pode ser considerada uma inovação na música brasileira. Nos discos anteriores de música instrumental, pode-se perceber que os músicos eram mais "recatados" no quesito execução, talvez pela concepção estética da bossa nova que, por sua vez, tinha uma determinada influência do Cool Jazz. Já no disco Embalo, percebemos essa liberdade harmônica e rítmica. Não que ele tenha sido o pioneiro, mas foi um disco que trouxe elementos inovadores que já podiam ser percebidos na obra de outros músicos da cena instrumental da época, como Paulo Moura.
\end{abstract}

O fato de Embalo ter sido reeditado em 2004 (pelo selo Dubas) ${ }^{6}$ nos dá indícios de um interesse pela redescoberta da sonoridade do sambajazz, possibilitando rememorar a figura de Tenório. Porém, é curioso como mesmo assim e com toda a importância que teve para a música brasileira o nome do pianista seja tão pouco evocado na academia, surgindo como um rosto borrado no conjunto dessas produções. Igualmente turvo, vale lembrar, foi o que the ocorreu naquela madrugada de 18 de março de 1976, em Buenos Aires.

60 disco também foi relançado pela Som Livre em 2006 (na série RGE Clássicos) e por selos no Japão (2006, Bomba Records) e na Inglaterra (2017, Mr. Bongo Records). 


\section{Sobre o tiro de misericórdia: breve imersão no cenário da tragédia de Tenório}

Era 20 de maio de 1986 quando o ex-oficial Claudio Vallejos, aproveitando o processo de desmantelamento dos regimes autoritários na América Latina, confessou à Senhor ter sido um dos responsáveis pela prisão, tortura e morte de Francisco Tenório Jr. Em seu depoimento, explicou que o músico teria sido abordado por oficiais em frente ao Hotel Normandie, na esquina da avenida Corrientes com a rua Rodríguez Penã. Um bilhete do pianista deixado no hotel informava que havia saído rapidamente naquela madrugada para "comer um sanduíche e comprar um remédio", convencido talvez de que a carteira profissional de músico e o fato de o pai ser um delegado bastassem para evitar problemas ${ }^{7}$. Mas a documentação não satisfez as autoridades, que optaram por prendê-lo, conduzindo-o até a Comissaria 5A, delegacia localizada na Rua Lavalle, próxima à ESMA (Escola Mecânica Armada), conhecida pelo histórico de crimes perpetrados pela ditadura argentina. Lá, Tenório seria torturado por dias, com direito a choques elétricos, e depois assassinado.

Naquela manhã em que prenderam o músico e outras pessoas, os oficiais do Serviço de Informações estavam à procura de Ricardo Caño, filho de um dos fundadores dos Montoneros, e que, segundo informações, faria uma aliança com o Exército Revolucionário do Povo. É quase consenso nas interpretações, influenciadas pelo depoimento de Vallejos, de que Tenório teria sido confundido; que era o homem errado na hora errada; que por conta de sua aparência "desleixada" e "rebelde" (barba e cabelos compridos), estaria incorporando todos os elementos pretensamente comunistas/subversivos aos olhos da polícia. Segundo Vallejos, além da "aparência suspeita", a situação de Tenório se complicou mais ao saberem que estava com Vinícius de Moraes, já conhecido por sua postura política. Embora absurda, a atitude parecia alinhada a um cenário que, à sua maneira, considerava cantores/compositores mais influentes, e, portanto, mais "perigosos" do que instrumentistas. Curioso como no martelo de pilão dos golpistas argentinos as suspeitas sobre Tenório se elevaram ao saberem quem ele acompanhava. Já no Brasil, anos antes, Caetano e Gil haviam sido presos por causa de um show "subversivo" na Boate Sucata, mas os músicos d'Os Mutantes, que os acompanhavam, não ${ }^{8}$.

\footnotetext{
7 Ao narrar esse episódio, Oliveira (1997; 2017) e outros que cultuam a genialidade de Tenório, o pintam como figura quase mítica, dotado de aura superior: músico preocupado só e somente só com os valores e práticas da arte; tanto que, não apenas não teria qualquer posição partidária, como viveria desconectado de seu entorno. A propósito, recordando uma publicação da Veja de 24/12/1975 acerca das tensões na Argentina, Oliveira (1997, p. 179) alega que tentou mostrar a Tenório "a ação da máquina política internacional também sobre o Brasil, particularmente sobre nossa música", mas Tenório era "impermeável a política". 0 autor, aliás, afirma e insinua reiteradas vezes no livro sobre uma postura alienada dos instrumentistas com quem tinha contato, mais voltados a uma espécie de "sacerdócio artístico", sendo essa posição quase majoritária. Cabe a reflexão: além da preferência pelo conteúdo lírico e por trajetórias ligadas à canção, teria sido este outro fator determinante nos rumos da historiografia musical? Isto é, um desinteresse pela música instrumental por conta da falta de indícios de engajamento dos jazzistas brasileiros?

8 Episódios assim nos fazem refletir sobre a hierarquização no campo da música popular e o seu reflexo no período ditatorial. Piedade (2006, p. 931-932) nos informa que na MPB há uma evidente distinção entre cantores e instrumentistas, e que "não é possível um igualitarismo completo em música, onde é constante o jogo entre frente e fundo, significado literal e profundo". Caberia discutir como isso se comportou no período de formação da MPB, quando fatores extramusicais, como o posicionamento político dos artistas, entravam em questão. Parece-nos que se pouco ou nada se pesquisou sobre o impacto das canções que se tornaram instrumentais por conta da censura, ou de produções originalmente instrumentais com teor político, e até mesmo sobre a (igualmente política) postura desinteressada de vários instrumentistas, isto tem relação com uma "surdez" acadêmica que age em consonância com determinados preconceitos, valores e preferências estéticas.
} 
De volta a Buenos Aires, Tenório tivesse ou não dimensão do que acontecia em solo argentino, fora ali que se deu a primeira reunião entre representantes de setores da inteligência de países do Cone Sul, em Santiago (Chile), em 1975, formalizando, assim, a Operação Condor: sombria aliança político-militar entre regimes autoritários com o objetivo de combater uma suposta união das esquerdas da América Latina e de outros países. Chile e Argentina mantinham estreitas relações nesse esquema internacional; algo ensaiado desde o atentado em Buenos Aires contra o general Carlos Prats, ex-ministro de Pinochet (QUADRAT, 2002).

Portanto, até aquela abordagem a Tenório acontecer, muita repressão já tinha sido empregada contra grupos contrários à ditadura, contando com a participação da Aliança Anticomunista Argentina, cujas ações criminosas eram permitidas pelas autoridades. Não é para menos que o clima político em Buenos Aires estivesse em ebulição em 1976.

Segundo Vallejos, o SNI informou que Tenório não tinha antecedentes políticos, que era inocente, mas sabia também que "ele tinha muitos amigos comunistas" (1986, p. 49), motivo pelo qual autorizou-se que fosse pressionado a dar nomes e informações. Não suportando mais as agressões, o pianista teria, então, revelado o nome de "músicos brasileiros que tinham ideias políticas, mas não eram ativistas" (1986, p. 49); possivelmente, não se tratava de cantores/compositores abertamente contrários à ditadura, mas, talvez, de instrumentistas que responsabilizavam o governo militar pelo estado de coisas que os desvalorizava no Brasil ${ }^{9}$. Não era o suficiente para serem alvos de perseguição política. Por isso diz-se que, para os argentinos, "Tenório já não interessava [mais]" (idem). Mas interessava ao SNI e à Embaixada brasileira, que permitiram que os suplícios prosseguissem. A passividade nada gratuita do Estado fez o resto, e o crime, cometido $^{10}$ : Tenório foi morto com um tiro na cabeça pelo comandante Alfredo Ignacio Astiz, alcunhado de Anjo da Morte ${ }^{11}$.

Em documento oficial assinado pelo capitão Jorge Eduardo Acosta (um ofício da Armada Argentina datado de 25/03/1976), a morte do músico é tratada como se fosse algo banal, desimportante:

1. Lamentamos informar a essa representação diplomática o falecimento do cidadão brasileiro Francisco Tenório Júnior, Passaporte no 197.803, de 35 anos,

9 Como se desprende do comentário da pianista Tânia Maria. Cf. Folha Online - Ilustrada - Tânia Maria rompe 30 anos de "exílio" musical $\underline{02 / 03 / 2005 \text { (uol.com.br) }}$

10 Em nível de informação, apenas em 2006 a Comissão Especial sobre Mortos e Desaparecidos Políticos confessou a "omissão do Estado brasileiro em proteger a vida e a integridade física de Francisco Tenório Cerqueira Júnior" (CNV, 2014a, p. 254). Em 2012, o procurador Miguel Ángel Osorio, responsável pela investigação judicial da Operação Condor na Argentina cobrou da Justiça Federal reconhecimento institucional de que Tenório foi vítima da Operação. No mesmo ano, por iniciativa do deputado socialista argentino Raúl Puy, colocou-se uma placa no Hotel Normandie, com os dizeres: "aqui se hospedou em sua última visita a Buenos Aires este brilhante músico brasileiro de Toquinho e Vinícius, uma vítima da ditadura argentina", bem como inscreveu-se o nome do músico no monumento dedicado aos mortos e desaparecidos pelo regime, no Parque da Memória, também em Buenos Aires. Por essa época, a ex-mulher de Tenório foi indenizada pelo governo argentino, mas apenas em 2014 conseguiu apresentar sua versão dos fatos ao governo brasileiro. Segundo o relatório da CNV (2014b, p. 353) os restos mortais de Tenório jamais foram reclamados pelo Estado brasileiro.

11 De tão polêmico, o depoimento, que delatava a omissão do ministro-conselheiro Marcos Cortes e a participação, como torturadores, dos majors Souza Batista e Batista Vieira; capitães Mário Lagos e Luís Visconti; agentes Carlos Barreto, Marcelo Castro e Henrique Guimarães, foi inserido no documentário "Balada para Tenório" do cineasta Rogério Lima, rebatizado de "Tenório Jr.?" de 1986, depois relançado em 1996. 
músico de profissão, residente na cidade do Rio de Janeiro; 2 . O mesmo encontrava-se detido à disposição do Poder Executivo Nacional, o que foi oportunamente informado a esta Embaixada; 3. O cadáver encontra-se à disposição da embaixada na morgue judicial da cidade de Buenos Aires, para onde foi remetido para a devida autópsia ${ }^{12}$.

Ao contrário de certas narrativas que tendem a mirar num "erro de cálculo" dos torturadores - pelo fato de Tenório não ter ligações partidárias ${ }^{13}$-, é de se convir que justamente por ser um instrumentista que gozava de certo prestígio em meios supostamente distantes do exercício político, e que circulava por ambientes da classe média, que o músico, vivo, poderia ser bastante incômodo para a ditadura brasileira, cujo autoritarismo agia a pretexto da Doutrina de Segurança Nacional. Além disso, Tenório não estava em território nacional, o que poderia facilitar no encobrimento do envolvimento de militares brasileiros.

Os golpistas argentinos podem não ter se interessado por Tenório (nem os censores brasileiros, obcecados por letras de canções e discursos panfletários), o público de Buenos Aires, porém, esteve com olhos e ouvidos bastante atentos ao trabalho do músico, especialmente à sua composição "Tamanduá", como indicava uma matéria sobre a apresentação da trupe liderada por Vinícius de Moraes no Teatro Gran Rex:

O espetáculo apresentou uma revelação que surpreendeu muitos espectadores: o excelente trabalho de Tenório Jr. O pianista, além de acompanhar eficazmente, executou uma brilhante composição que, paradoxalmente, se constituiu na mais autêntica expressão da música contemporânea brasileira (grifos nossos) ${ }^{14}$.

Vale observar que algumas personalidades da música e críticos brasileiros à moda de José Ramos Tinhorão, que se posicionavam de maneira feroz contra a influência do jazz, provavelmente não corroborariam com tal comentário, vendo músicos da cepa de Tenório como verdadeiros "alienados", agentes contra a "autêntica música brasileira", e, portanto, esteticamente desinteressantes; indignos dos holofotes da consagração e da memória ${ }^{15}$. Aliás, a cobertura da morte e o trato com a memória do pianista, como discutiremos a seguir, comportaram-se de maneira bastante irregular, disforme e nebulosa.

\footnotetext{
12 Segundo Vallejos, o corpo de Tenório foi enterrado no cemitério de La Chacarita, registrado sob o nome falso de Marcelo Fernandez, setor A, lado V, n 3881. Comprovou-se mais tarde que era uma informação falsa. Para o atestado de óbito cf. https://documentosrevelados.com.br/ wp-content/uploads/2017/11/tenorio-apenas.pdf.

13 Oliveira (2017, p. 150) apresenta novo dado sobre a posição política de Tenório. Sem citar nomes, informa que um músico amigo do pianista garante que ele era de direita e que apoiava os militares, o que não é todo improvável, já que era filho de um delegado de polícia. Em todo caso, se verdadeira, a especulação só tornaria ainda mais irônica a sua tragédia, embora, havemos de convir, não fosse atípico de ditaduras atingir também os seus apoiadores declarados.

14 Jornal El Cronista Comercial, 18/03/1976. Cf. Jornal O Rebate - Quando Vinicius procurou Tenório Jr. em Buenos Aires - Jornal O Rebate

15 Cf. RIBEIRO JÚNIOR, 2018, p. 52-122.
} 


\title{
Ecos de uma nota interrompida: dissonâncias e improvisos sobre a morte de Tenório
}

\begin{abstract}
Nos estertores da censura de 1976, o tema "Tenório Jr." ainda era tabu. O máximo que se podia fazer - e se fazia - era perguntar regularmente onde estaria o músico que gravou o LP Embalo em 1964 e que, além de Toquinho \& Vinícius, trabalhara com Milton Nascimento, Edu Lobo, Joyce, Lô Borges e Beto Guedes (BAHIANA, 2006, p. 267).
\end{abstract}

No tocante ao suposto "silenciamento" da memória de Tenório, entendemos que seria equivocado afirmar que sua história não foi divulgada nos veículos de imprensa e outras mídias. Antes pelo contrário. No cenário internacional, o jornal La Razón daquele março agitado enfatizava em letras cavalares: "Vinícius de Moraes solicitou ajuda para encontrar seu pianista", como resposta às diversas tentativas do ex-Itamaraty na busca pelo paradeiro de Tenório, fora suas iniciativas frustradas em favor da integridade física do músico desaparecido ${ }^{16}$. No Brasil, seu desaparecimento foi primeiramente noticiado em 22 de março de 1976, numa curta e tímida nota no Jornal do Brasil (1을 caderno, p. 12). Em seguida, foi a vez do Estado de São Paulo, Folha de São Paulo, O Globo, Última Hora e Estado de Minas. Tanto nos jornais argentinos quanto nos brasileiros geralmente Tenório era tratado como "pianista de Vinícius de Moraes", indicando, talvez, certa hierarquização, já incorporada e naturalizada no discurso midiático.

No meio musical, o grupo Sombras (Sociedade Musical Brasileira), formado por nomes como Hermínio Bello de Carvalho, Sérgio Ricardo, Jards Macalé e Aldir Blanc, pressionou o ministro de relações exteriores, Azeredo da Silveira, exigindo que se tomassem providências para a resolução do paradeiro de Tenório, "competente instrumentista e pessoa estimada por toda a nossa classe" (O Globo, 26/03/1976). Em maio, o grupo realizou um evento no Teatro João Caetano chamado "Ação Entre Amigos", para arrecadar recursos para a família do pianista, tendo a participação de Milton Nascimento, Luís Gonzaga Júnior, João Bosco, Nana Caymmi, Egberto Gismonti, entre outros. Hermínio Bello, já ciente da inoperância do Estado, desabafou: "surpreendentemente, até agora, o Itamaraty não nos respondeu nem deu qualquer mostra de preocupação maior com o caso" (Folha de S. Paulo, 3/5/1976, p. 19).

Após três anos de silêncio, Elis Regina informou ao Folha de S. Paulo que planejava ir até Buenos Aires buscar Tenorinho, pois tinha informações de que ele "estava vivo em uma prisão de La Plata" (Folha de São Paulo, Folhetim, 3/6/1979, p. 03). No mesmo ano dedicou o disco Essa Mulher (WEA), "à presença de Bituca. À ausência de Tenório Jr.". Já Toquinho, que como o baterista Mutinho e o baixista Azeitona, tocou com Tenório naquela turnê pelo Uruguai-Argentina, homenageou o músico em $1981 \mathrm{com}$ a canção "Lembranças" do disco Doce Vida (Ariola): "Tenório saiu sozinho na noite/sumiu ninguém sabe explicar/outros amigos se foram/guardando os seus ideais/entre verdade e

16 Através de um juiz, Vinícius tentou articular um pedido de habeas corpus, temendo pela vida de Tenório. A empreitada, porém, foi calada pela repressão, que se radicalizou ainda mais com o golpe protagonizado por Jorge Rafael Videla contra o governo de Isabelita Perón. Mais informações cf. Jornal O Rebate - Quando Vinicius procurou Tenório Jr. em Buenos Aires - Jornal O Rebate. 
delírio/uns semearam saudade do exílio/outros não voltam jamais"17. Em seguida, numa primeira manifestação pública sobre o caso, e já intuindo o que sucedera ao pianista, Frederico Mendonça de Oliveira, conhecido como Fredera, ex-guitarrista do Som Imaginário, dedicou a faixa "Um bolerésio", do LP Aurora Vermelha (1981, Som da Gente), "para Tenório Jr., no céu".

Como uma das primeiras vítimas da Operação Condor, o nome de Francisco Tenório Cerqueira Jr. (entre outros brasileiros engolidos pela ditadura argentina) aparece em documentos importantes em favor dos Direitos Humanos. Por exemplo, no informe para a América Latina do Mopassol (Movimiento por la Paz, la Soberanía y la Solidaridad entre los Pueblos), de 1993; nos relatórios da Comissão Nacional da Verdade, nos quais se disserta sobre seu assassinato em dois capítulos ${ }^{18}$; em A Ditadura Encurralada (2014), Elio Gaspari o cita, embora muito brevemente; no livro Operacíon Condor: pacto criminal (2016) da jornalista argentina Stella Calloni há uma reconstituição do caso com mais detalhes - feito parecido da obra Nuestro Vinicius. Vinicius de Moraes em el Río de la Plata: um perfil em várias vozes (2010) da jornalista Liana Wenner. Além disso, em nosso levantamento nos deparamos com um número expressivo de matérias sobre Tenório em blogs e jornais eletrônicos. Também encontramos algumas reportagens feitas por canais de TV como a Globo ${ }^{19}$ e a argentina Telesur ${ }^{20}$. Além do documentário de Rogério Lima, nos deparamos com o filme provisoriamente intitulado de "Tenório" do espanhol Fernando Trueba, que visa tratar "sobre música, memória e a barbárie do fascismo"21.

Sendo assim, de antemão, se poderia supor que a segunda morte de Tenório Jr. (a da memória) não faria sentido tendo em vista a quantidade de notícias - que foram veiculadas de forma bastante aleatória -, mas, sim, pelo impacto que tiveram na sociedade brasileira: algo conectado mais ao que Tenório significava para o país que pelo volume de informações, cuja extensão foi/é motivada, naturalmente, pelo combate aos horrores da ditadura.

Diante disso, vemos o caso de uma trajetória pessoal que ao longo do tempo, e por iniciativas muito pontuais, permaneceu na corda-bamba da memória; equilibrando-se entre o subsolo e a superfície desse campo. Ou, para usar uma expressão de Pollak (1989), uma "memória subterrânea", lutando para se institucionalizar através de análises sobre regimes de exceção na América Latina. Porém, quando absorvido pela memória coletiva da ditadura, as questões do campo musical brasileiro representadas pela carreira de Tenório foram, muitas vezes, deixadas em segundo plano, subsumidas,

\footnotetext{
17 O cantor repetiu o feito em "Até logo, companheiro", última faixa do disco Só tenho tempo para ser feliz (Movieplay, 2003) e que deriva da tradução de Augusto de Campos do poema-carta-de-suicídio de Sierguéi lessiênin: "até logo, até logo, companheiro/eu te guardo no meu peito e te asseguro/nosso afastamento passageiro/é sinal de um encontro no futuro...."

18 Cf. Seção "Cidadãos brasileiros desaparecidos na Argentina no marco da Operação Condor" (Comissão da Verdade, Vol I: Conexões Internacionais: a aliança repressiva no cone sul e a Operação Condor, dezembro, 2014); Seção 1.3 dos "estudos de caso" (CV, Vol II: A resistência da sociedade civil às graves violações dos direitos humanos, dezembro, 2014).

19 Reportagem de 2016, disponível em: (20) Tenorio Jr, el pianista brasileño desaparecido en dictadura argentina - YouTube.

20 Em 1992 saiu a primeira reportagem da Globo sobre o caso no programa Fantástico: (20) Em busca de Tenório Jr - YouTube.

21 Cf. Fernando Trueba ya escribe el guión de su segunda película de animación (abc.es).
} 
subvalorizadas. De outro lado, há quem preferiu focar na produção de Tenório sem problematizar as narrativas sobre e para além dele.

De volta às versões sobre o ocorrido ao pianista, o produtor musical Lafayette Hohagen retoma toda a história do assassinato, mas acrescenta um elemento novo: uma carta supostamente escrita por Tenório em 1969 e a ele endereçada. À época, vivendo no Rio de Janeiro, o músico teria lamentado ao amigo de São Paulo que "a vida está cara e quase não há trabalho para músicos...". Nesta mesma carta, o pianista informava que estava tocando com a Turma da Pilantragem, chegando a afirmar que embora o movimento fosse "destituído de qualquer valor artístico, [estava] tendo êxito comercial, o que é bastante para que os produtores inundem a praça com isso... Aqui não se faz outra coisa..."22.

Forneceria o conteúdo da missiva indícios que corroboram com a afirmação de Castro (2017) e Oliveira (1997; 2017) de que, a partir de 1966, os instrumentistas teriam se tornado meros acompanhantes dos cantores, renunciando a projetos mais ousados na composição instrumental? Teria sido por essa razão que Tenório não apenas precisou aceitar trabalhos com os quais não se identificava musicalmente, mas justificou também sua partida em turnê com Vinícius de Moraes e cia para Buenos Aires?

Reconhecendo que as narrativas sobre Tenório, mesmo que vítima cujo corpo nunca foi encontrado, portanto representante de um luto em aberto, não encontraram o alcance devido na historiografia e na memória brasileira (não obstante todos os burburinhos na grande imprensa e, mais recentemente, em documentos da Comissão da Verdade), cabe, agora, examinar, a partir da obra Um crime contra Tenório, de que maneira a trajetória do músico foi tratada.

\title{
Os rastros de Tenório nos (des)embalos da memória musical brasileira
}

\begin{abstract}
Há uma conspiração do silêncio contra o músico [...]. O violonista Toquinho, um dos últimos a estar num palco com Tenorinho, também foi procurado por Época para relatar aquele momento. Respondeu pela secretária eletrônica: "Você sabe quem eu sou". Com certeza. O que talvez nunca mais se saiba é quem foi Tenorinho na voz dos que o conheceram (MAYRINK, 2010, s/p).
\end{abstract}

Nascido em 20 de maio de 1945, alguns anos depois de Tenório, e também natural do Rio de Janeiro, Frederico Mendonça de Oliveira iniciou sua carreira musical por volta de 1968, em plenos Anos de Chumbo. Do mesmo modo que Tenório, abandonou a formação superior (em Letras) para se dedicar somente à música, também atuando ativamente entre 60 e 70, quando acompanhou diversos cantores da MPB, tais como Caetano Veloso, Gal Costa, Gilberto Gil, Gonzaguinha, Ivan Lins, Marcos Valle, entre outros. Nesse ínterim, o guitarrista contribuiu em movimentos musicais marcantes como a Turma da Pilantragem, composto por Wilson Simonal, Nonato Buzar, Cassiano; músicos: 
Márcio Montarroyos, Raul de Souza, José Roberto Bertrami, Victor Manga; participou também do Clube da Esquina, lembrado por nomes como Milton Nascimento, Wagner Tiso Beto Guedes e Lô Borges.

Por essa época, entre 1974 e 1976, Frederico de Oliveira manteve contato significativo com Tenório Jr., compartilhando experiências do cotidiano profissional. Em sua obra, o músico alega ter sido um dos últimos a ver o pianista vivo, no Brasil, presenciando o momento em que ele tomou o táxi rumo ao aeroporto.

A propósito, em seu livro, a morte de Tenório é apresentada como "violenta metáfora para representar como síntese o que sofreram os músicos instrumentistas brasileiros desde a instalação de ditaduras de direita na América Latina na década de 70" (1997, p. 21), argumento que intentamos problematizar a partir de agora. Antes, vale destacar que a assertiva sobre o boicote ao instrumental foi atualizada na segunda edição da obra, evitando mencionar a ditadura, e culpabilizando "a implantação do 'mercado da canção', pernicioso instrumento político da intervenção já em marcha" (2017, p. 15) ${ }^{23}$. Para o autor, a partir de 1964, teria havido um suposto conluio que envolveu multinacionais, o governo e os artistas vinculados à MPB para supervalorizar a canção popular, tornando-a rentável produto de mercado e banindo (se não, subdimensionando) a música instrumental. Essa suposta trama teria alcançado seu clímax com os Festivais Internacionais da Canção (1966-1972), quando a grande mídia se voltou para a canção, amplificando a imagem de compositores e intérpretes, e difundindo massivamente, também, valores extramusicais através dessas produções.

Um ponto que queremos destacar é que, na tentativa de legitimar sua tese, o autor enfatiza sua posição de testemunha ocular dos eventos. Desse modo, aciona sua carreira musical como fato que the permite reclamar a autoridade/credibilidade dos instrumentistas para escrever suas próprias narrativas sobre a música brasileira. Lança, então, críticas à expressiva bibliografia de jornalistas e acadêmicos sem ligação direta com o ofício musical:

Nas páginas deste livro o leitor se haverá com o ponto de vista desse profissional preterido a partir do golpe e da instituição das regras e das leis do mercado pós-golpe [...]. A maioria dos autores - críticos, historiadores, exegetas, pesquisadores, interessados, aficionados, curiosos - que abordou o assunto até o momento jamais se referiu ao instrumentista como protagonista, coadjuvante ou o que quer que seja dentro do cenário musical [...]. O ponto de vista emitido aqui é o do músico instrumentista, cujo depoimento raríssimas vezes foi incluído em qualquer publicação oficial da imprensa a serviço do regime e/ou do mercado. Estão vivos aqui os protestos abafados de gente como Edison Machado, Maciel, Jorginho da Flauta,

\footnotetext{
23 Assim que publicado, houve um conflito envolvendo o autor e a família do músico. O procurador da família, Claudio Bedran Gomes, acusou o autor de "oportunismo", afirmando que Frederico não obtivera autorização dos familiares para a publicação (argumento refutado pelo guitarrista), repudiando também o fato de o autor ter se baseado em apenas uma fonte de informação para elaboração da obra. Possivelmente, um agravante teria sido o conteúdo ideológico que atravessa o livro. 0 atrito pode ter sido influenciado ainda pelas circunstâncias. Àquela altura, a família de Tenório ainda deveria estar bastante afetada, pois permanecia numa busca incessante por respostas e direitos. A viúva de Tenório, por exemplo, naquele mesmo ano, requereu a reabertura do caso e o pagamento de uma indenização pelo governo argentino, contando com o suporte do Ministério da Justiça e de associações de direitos humanos. Sobre o conflito entre Fredera e a família de Tenório Jr. cf. Folha de S.Paulo - Família de pianista morto repudia livro - 10/6/1997 (uol.com.br).
} 
Maurício Einhorn, Raulzinho Trombone, Luís Eça e de todo um contingente de profissionais especializados... (OLIVEIRA, 1997, p. 23-24, grifos nossos).

Uma vez afirmado o seu lugar de fala nos enunciados sobre a música brasileira, Oliveira denuncia, então, a segunda morte de Tenório, o da memória, que despontaria como evidência inequívoca da progressiva desvalorização da música instrumental no Brasil. Em outros termos, Oliveira defende que este apagamento que recairia sobre Tenório e, consequentemente, sobre outros músicos, foi motivado por essa abrupta transformação nas formas de consumo, apreciação e valorização da música instrumental propagados pelos festivais e adotados pelas gravadoras.

Vale destacar que Oliveira não é a única voz a defender esta tese. Retomando implicitamente a metáfora-premissa do guitarrista, Ruy Castro (2017) assim intitulou um dos capítulos de seu livro A onda que se ergueu no mar: "Atire no pianista. E também no saxofonista, no trompetista, no trombonista...". Revisitando a história de Tenório, o título do texto fala por si só e resume bem que posicionamento o autor assume ao tratar sobre o lugar da música instrumental (e dos instrumentistas) na memória musical brasileira; por conseguinte, na forma de tratamento que esses sons e esses artistas recebem atualmente.

Além do suposto oblívio que teria recaído sobre o caso do pianista, tanto no Brasil quanto na Argentina, "apesar de pastas abarrotadas de material de imprensa a seu respeito" (CASTRO, 2017, p. 215), Ruy Castro expressa de maneira incisiva que

Tenório Jr. parece não existir também para fins artísticos em seu próprio país. Seu nome não é verbete das enciclopédias da música popular brasileira, algumas com quase mil páginas e contendo nomes menoríssimos (sic), surgidos dias antes de esses livros irem para o prelo. Tenório não é sequer mencionado em verbetes alheios. Também, pudera: não era um cantor, uma celebridade, um astro da "MPB". Era apenas um músico (2017, p. 215) ${ }^{24}$.

E diz mais: "como Tenório Jr., nenhum deles - Edison Machado, Maciel 'Maluco', Tião Neto, Mario Telles e outros que sonharam com uma grande música instrumental brasileira - consta das enciclopédias de música popular" (CASTRO, 2017, p. 228).

Reforçando a noção de uma fase heroica da MPM, Castro (2017, p. 220) informa que em meados dos anos 60, "nada parecia deter o sambajazz: havia músicos, repertório, um público pequeno, mas cativo, e, pelo visto, gravadoras inteligentes, dispostas a se deixar fecundar", mas que logo houve "súbita mudança da música popular a partir de 1966, quando os praticantes dos vários instrumentos, que não as guitarras, foram praticamente expulsos do país" (CASTRO, 2007, p. 367). A partir de então, motivada por fatores externos e políticos, "a música brasileira começou a seguir novos rumos, todos hostis à Bossa" (2017, p. 316). Em suma, supostamente o instrumental teria começado

24 Segundo o crítico Tárik de Souza (Jornal do Brasil, 17/04/1977, caderno b, p. 09) o nome de Tenório Jr. constava no verbete do Dicionário Biográfico de Música Popular (1965), "o único existente no Brasil", de autoria do também crítico musical Sylvio Túlio Cardoso. 0 que poderia significar, tomando esta afirmação de Ruy Castro, que se trata de uma exceção, considerando o ano em que foi publicada a obra. Ou seja, quando o sambajazz ainda era influente. Verificamos ainda que na Enciclopédia da Música Brasileira (1977) não se cita o nome de Tenório. Já no Dicionário da Música Brasileira (2006, p. 729) há um verbete curto sobre o pianista, que nem sequer cita sua data de nascimento. 
a ser desvalorizado por conta da "cancionização" da música brasileira, dando vasão a uma nova disposição estética que preteria de uma vez por todas a improvisação jazzística (para o prazer dos nacionalistas), abrindo caminho para a hegemonia da MPB - complexo cultural que, embora houvesse produzido músicas com qualidade lírica e instrumental, sustentou-se pelo culto à imagem de seus cantores e intérpretes. Tal "inversão de valores" teria golpeado mortalmente a carreira de vários músicos brasileiros, levando-os ao esquecimento e forçando muitos deles a sair do país.

Oliveira (2007, s/p) também endossa essa visão. Ao analisar a importância do disco Embalo para a música brasileira e para a música popular britânica, comenta que:

O samba-jazz parecia se encaminhar para a consagração [...]. Em 1966, contudo, as gravadoras dispensaram quase a totalidade dos músicos do seu elenco [...]. A hipótese segunda a qual o movimento do samba-jazz ou da música popular moderna foi vítima de uma sabotagem mercadológica apareceu no livro $\mathrm{O}$ crime contra Tenório... As consequências deste fato implicaram em vários fatores, como a predominância do chamado estilo MPB [...], em que o 'cancionismo' adotou os instrumentistas que tiveram as portas fechadas através das atitudes das gravadoras em 1966.

O crítico musical Aluízio Falcão (2017) confronta esta narrativa, tomando-a como panfletária, anti-cancionista. Dessa forma, o jornalista sai em defesa da MPB e da canção popular, afirmando que esta jamais foi privilegiada em detrimento da música instrumental. E lança uma crítica contundente ao livro de Frederico:

Em 1953, Guinle foi didático e persuasivo em seu livrinho [Jazz Panorama]. Explicou o jazz, não hostilizou o cancionismo. Diferentemente de Frederico Mendonça de Oliveira (o conhecido guitarrista Fredera) que em 1997 lançou um furioso manifesto contra a música vocal [...]. Não apenas Tenório morrera, disse ele, mas todos os instrumentistas brasileiros empenhados na elaboração de uma linguagem subsequente à bossa. Teriam sido vítimas de um complô das multinacionais do disco, unidas para promover o cancionismo [...]. Querendo sensibilizar os leitores politicamente corretos, Fredera não titubeia em usar o cadáver de Tenório. Nessa teoria conspiratória, para não dizer paranoica, denuncia os festivais iniciados em 1965 (muito antes da morte do pianista) como peça do complô. O fato de alguns terem surgido como 'festivais da canção' e não 'festivais da música', evidenciaria o propósito destruidor. Puro delírio (2017, s/p).

O autor afirma ainda que o "rancor anti-cancionista de Fredera tem adeptos até hoje" e que "não é segredo no meio musical a implicância de alguns instrumentistas com grandes autores de música e letra" (FALCÃO, 2017, s/p).

Embora seja uma interessante nota dissonante, a interpretação de Falcão, porém, é fruto de uma leitura superficial do livro de Frederico Oliveira, não atentando para o fato de que o autor, ainda que confronte a "MPB", não necessariamente desqualifica todo o universo da canção, distinguindo-a em "canção na ditadura" e "canção da ditadura".

No primeiro grupo, estariam os que se beneficiaram do novo establishment, ainda 
que fossem abertamente contrários ao regime militar; que não eram propriamente instrumentistas, mas que produziram composições de qualidade. Nem sempre com refinamento instrumental, segundo o autor. No outro grupo, distintamente, estaria a Jovem Guarda, sobretudo Roberto Carlos (vistos como símbolo de um retrocesso iniciado nos EUA com o advento do rock n' roll), e artistas como Dom e Ravel: nomes que Oliveira ataca ferozmente na primeira edição do livro pelo seu alinhamento à ditadura; depois, vem a Pilantragem, que mesmo que contasse com excelentes instrumentistas (incluindo o próprio autor, vale lembrar) acabou, segundo Oliveira, sucumbindo aos ditames do mercado, simbolizando, enfim, um "segundo desvio... para um desregramento não só musical, mas de costumes também" (1997, p. 67). Por último, cita certas composições da Tropicália produzidas nos anos 70. Para o autor, em suma, havia canções e canções, mas ambas acabaram favorecendo interesses políticos e mercadológicos que preteriam o formato instrumental.

Deslocando-se da tensão cancionismo versus anticancionismo, outra narrativa associa a falência da qualidade instrumental ao ambiente truculento da ditadura (lido como averso à total liberdade criativa), e não diretamente ao lobby gravadoras/mercado/meios de comunicação:

O período militar brasileiro, que assolou a produção cultural no final dos anos 60 , tornou exígua qualquer esperança de fazer música que não habitasse os territórios consentidos pelo governo. A repreensão foi sentida principalmente por artistas experimentais, vindos da música instrumental. Com a censura, muitos músicos foram obrigados a criar em terras estrangeiras (ROSAS, 2015, s/p, grifos nossos).

Percebemos que além das muitas variáveis nos relatos sobre o caso de Tenório, há, nesse sentido, divergências no trato com a relação entre instrumental, canção e regime militar; discrepâncias que se valem, muitas vezes, da figura do pianista, não apenas para ilustrar o argumento, mas para instrumentalizar toda a carga simbólica que enreda a sua memória em favor de preferências políticas e estéticas, bem como interesses simbólicos e de classe. Para além de questões eminentemente econômicas e estéticas, a posição política de Oliveira, por exemplo, fica evidente quando afirma que a ditadura ocorreu para evitar a "implantação de governos de esquerda, que estabeleceriam ditaduras do proletariado nos anos 1970 - por sinal, década de ouro da canção conhecida como MPB no Brasil" (OLIVEIRA, 2017, p. 16), adicionando à sua tese sobre o boicote ao instrumental um conteúdo revisionista e reacionário.

Dessa forma, no campo de batalha dos bens culturais, manifestam-se conflitos nos quais está em jogo a "verdade" histórica sobre os fatos; pela definição dos "vencidos" e dos "vencedores"; "resistentes" e "integrados"; "favorecidos" e "marginalizados". Para validar tais definições, a memória irrompe como arma secreta dentro da arena de combate. Mas, além disso, uma vez que a memória coletiva (HALBWACHS, 1990) desponta também como território de disputas, onde narrativas se tensionam para se legitimar e se perpetuar (POLLAK, 1989), o que está em jogo é o próprio enquadramento da memória 
(POLLAK, 1992), em que pese, para uns, a manutenção da narrativa oficial da trajetória da música brasileira na ditadura e, para outros, a reedição dessa memória institucionalizada. No meio do confronto, o fantasma de Tenório - representado como "gênio", "virtuoso", "elevado" - é convocado como vítima, testemunha e prova incontestável dos acontecimentos; numa operação simbólica que recorre à via nebulosa que marcou a sua memória, politizando-a e entrelaçando-a à acalorada discussão sobre a situação (descontínua para uns, questionável para outros e decadente para outros mais) do jazz brasileiro entre 1960-70:

\begin{abstract}
A verdadeira vítima da censura acabou por ser o samba moderno que, pela ausência de palavras de tom político contidas nas letras das canções, passou então a ser desconsiderado em sua força política. A maior vítima do regime militar brasileiro na classe musical foi justamente o pianista Tenório Júnior, que jamais havia escrito uma palavra contra o Estado militar, mas era "fora do padrão" [...] quando ele "desapareceu", tinha aparência física considerada rebelde, pois usava cabelos e barbas grandes. E era praticante de uma marginalizada "música instrumental" (FRANÇA, 2015, p. 176).
\end{abstract}

Assim é que, passado o momento dos traumas da ditadura, as narrativas centradas no jazz brasileiro dos anos 60 e que militam em prol daquelas sonoridades, evocam a figura de Tenório, se apropriam dela, representam e a apresentam como elemento que confere autenticidade ao relato; trunfo para rearranjar a memória enquadrada da música brasileira.

Apesar das variações e dissonâncias no campo da memória musical, percebemos que é quase unânime nos discursos a opinião de que o jazz brasileiro foi realmente golpeado nos anos 60. Recorrendo a Bourdieu (2002), entendemos que tal opinião, longe de ser gratuita, ao reivindicar o reconhecimento e celebração de "músicos esquecidos" como Tenório, objetiva não apenas revestir-se de validade, como encontrar quem lhe faça eco, legitimando ainda mais o seu poder simbólico, a fim de sacudir os alicerces da hegemonia e dos consensos sobre a formação da MPB. Assim, aqueles agentes vinculados direta ou indiretamente ao sambajazz/MPM, uma vez posicionados em lugar mais justo na história e na memória musical, alcançariam, finalmente, através do equilíbrio de forças, o tão sonhado prestígio. Mas, em vez de tomar essas narrativas como verdades inquestionáveis, precisamos examinar a relação entre sambajazz, música instrumental e o mercado fonográfico naquele período.

\title{
A outra face dos fatos: jazz e música instrumental no início dos anos 1970 - Do "fim" do sambajazz ao adeus de Tenório Jr.
}

Através de nosso levantamento, verificamos que a situação estética e social da música instrumental e do jazz se alteraram profundamente a partir de 1967, momento de ebulição da tensão com o universo da canção, simbolizada na MPB. Se é possível dizer que o sambajazz já dava sinais de esgotamento desde meados de 1966, algo indubitável é que Tenório não gravou mais nenhum disco solo/autoral após Embalo (1964), 
consequência da correlação entre a nova dinâmica de mercado e seu impacto econômico na vida dos músicos ligados ao jazz, que, em fins dos anos 60, teriam de seguir as novas regras do jogo, se quisessem sobreviver às drásticas mudanças do mercado ${ }^{25}$.

Percebemos, também, que nesse mesmo período outras sonoridades passaram a fornecer subsídios para a formação do jazz brasileiro dos anos 1970, conectando-se cada vez mais umbilicalmente ao universo instrumental ${ }^{26}$. Ademais, o samba vai deixando de ser a principal matriz rítmica dessas propostas, dando mais espaço para gêneros como o baião, o frevo e o maracatu. O contato com o jazz também muda nesse contexto: antes focado no bebop, no cool e no hard, agora passa a incluir as eletrificações do fusion jazz como grande mediadora desse processo. A trajetória de Tenório é atingida por essa mudança, participando dos discos Egberto Gismonti (1973, Odeon) e Academia de Danças (1974, EMI), justo quando Egberto se aproxima da música improvisada mundial e passa a carregar "uma forte influência do jazz-rock ou fusion" (MOREIRA, 2016, p. 12; p. 100-107). Além desses, outros LPs que seguem uma linha vanguardista e que contaram com a participação de Tenório foram: o homônimo Lô Borges (Odeon, 1972), Missa Breve (Odeon, 1973) de Edu Lobo, Nana Caymmi (CID, 1975).

A partir da modernização tecnológica engendrada pelo regime militar, o campo da cultura e das artes sofreu intensas modificações durante os anos 1970. Pautado no objetivo de "integrar" o Brasil para disseminar suas imposições pautadas na lógica conspiratória da "segurança nacional", o governo promoveu um investimento nas indústrias de base, tornando possível, dessa forma, a construção de um mercado de bens culturais massivos, consolidado justamente durante tal década, promovendo uma intensa racionalização nos métodos de produção de bens artísticos (ORTIZ, 1988, p. 113-148). Dentro desse contexto, a indústria fonográfica brasileira cresceu como nunca, atingindo altas taxas de crescimento ininterruptas, de 1966 até 1979 (VICENTE, 2014, p. 50-51; DIAS, 2000, p. 59).

Segundo Morelli (2009, p. 61-109) e Fenerick (2007, p. 28-29), o mercado de música gravada em ascensão favoreceu a música cantada durante os anos 1970 e atuou na consolidação da MPB. Dessa forma, aglutinada em torno de uma proposta específica de brasilidade, a MPB consolidou-se enquanto "resistência" ao regime militar. Além disso, Vicente ressalta (2014, p. 74-75): os artistas de maior projeção nesse período eram justamente aqueles relacionados de alguma forma a esse núcleo da canção brasileira, todos eles contratados e vinculados às grandes gravadoras transnacionais (majors) da época.

\footnotetext{
25 Em carta endereçada à sua esposa, Carmem Magalhães Tenório Cerqueira, e publicada pelo Jornal do Brasil em 13/04/1976, Tenório fornece pistas sobre as dificuldades pelas quais passava: "estou trabalhando demais e ganhando muito menos do que nos shows aí no Brasil [...]. Tenho de aceitar o circuito, porque o dinheiro dessa viagem não está dos melhores, infelizmente..." (OLIVEIRA, 1997, p. 171). Outro exemplo era o baterista Milton Banana, que tentou gravar discos em homenagem a Chico Buarque, Tom Jobim e Vinicius de Moraes, "mas então o mercado não respondia" (CASTRO, 2017, p. 316). Inclusive, conta-se que por alguns anos o baterista precisou da ajuda financeira de João Gilberto para poder sobreviver (CASTRO, 2017, p. 317).

26 Dentre alguns artistas e bandas que podem nos auxiliar a compreender a transição da fórmula sambajazz para novas possibilidades no escopo do jazz brasileiro (desde o final dos anos 1960, passando pela década de 70 e 80), podemos citar: Tânia Maria, Márcio Montarroyos, Antonio Adolfo, Victor Assis Brasil, Banda Black Rio, Som Imaginário, Airto Moreira, Egberto Gismonti, Hermeto Pascoal, Azymuth, Dom Um Romão, Mauro Senise, Nico Assumpção, Nelson Ayres, Metalurgia, Freelarmônica, Pé Ante Pé, dentre muitas outras.
} 
Simultaneamente, figuras representativas da música instrumental e do jazz brasileiro se veem diante de sérias dificuldades para gravar, produzir e lançar seu material, não podendo contar com o amparo e parcerias de mesma condição que a música cantada. A MPB, por outro lado, se institucionaliza (NAPOLITANO, 2001) e torna-se um dos elementos mais representativos da cultura brasileira no período da ditadura civil-militar (1964-1985). Talvez, também por isso, o exílio de alguns artistas seja tão mencionado pela bibliografia, enquanto a morte de outros é citada pouquíssimas vezes, de forma coadjuvante e quase nunca relembrada como um acontecimento de mesmo nível de inteligibilidade para esse período histórico.

Ou seja, a partir desses diversos estudos que reiteram a consolidação da MPB (a partir da bossa nova) enquanto foco primordial da indústria fonográfica brasileira, talvez seja possível inferir: mesmo que o alargamento da censura após o Al-5 não interfira diretamente na música instrumental, devido à ausência de letra, no período entre 19681976 ocorre uma grande diminuição dessas propostas no mercado de música gravada, fortalecendo a necessidade de muitos instrumentistas acompanharem os intérpretes e cantores. Não por acaso, Tânia Maria, Egberto Gismonti, Hermeto Pascoal e Airto Moreira - provavelmente os quatro principais nomes que representam a transição da fórmula sambajazz para o experimentalismo do jazz brasileiro e/ou da Música Popular Instrumental Brasileira dos anos 1970 (MPIB) - construíram suas carreiras, principalmente, fora do Brasil. As dificuldades encontradas pelos músicos do jazz brasileiro e suas trajetórias em solo nacional parecem corroborar com as intempéries relacionadas à produção fonográfica de Tenório Jr.

Percebemos, então, que são muitos os elementos que contribuíram para o ofuscamento da música instrumental e do jazz brasileiro da maioria dos contratos com as gravadoras de grande porte radicadas no Brasil. Dentre eles, um fator essencial é a intensa racionalização do mercado fonográfico como um todo, reorganizando seu modus operandi a partir da globalização e da mundialização da cultura (DIAS, 2000). Isto é, as gravadoras estavam privilegiando investimentos de baixo investimento para concretizar o lançamento de determinado material gravado no mercado, focando cada vez mais no corte de custos e nas possibilidades de alto rendimento (a partir de nomes já referendados pelo público, por exemplo) (MORELLI, 2009, p. 62).

Assim, o universo do experimentalismo e da artesanalidade, intensamente conectados à música instrumental, ficaram cada vez mais distantes da cadeia produtiva da indústria fonográfica brasileira, justamente a partir do final dos anos 1960 e início dos 1970. Nesse cenário, o disco Embalo, apesar de seu engendramento com o sambajazz e a bossa nova, parece não ter encontrado grandes meios de divulgação e circulação na produção e na memória musical brasileira, podendo ser compreendido como um índice bastante sensível a essa problemática. Como demonstramos no primeiro tópico, Tenório gravou com diversos artistas da canção, simbolizando esse contexto de entrelaçamento desigual entre canção e instrumental.

Conforme salienta a pesquisa de Morelli (2009), logo após o Al-5, as gravadoras instaladas no Brasil definiram a veiculação de música estrangeira (matriz gravada fora 
do Brasil) como principal plano de atuação, justamente no mesmo momento em que as transnacionais do setor iniciam ou ampliam sua atuação no país, algo que se potencializaria na década seguinte, pois, os custos de gravação, na primeira metade dos anos 1970 eram altíssimos. Quanto a isso, segundo a autora:

1968 constitui também um ponto de referência para as histórias interligadas da indústria fonográfica do Brasil e da música popular brasileira da década de 1970 (...) sendo subsidiárias de grandes grupos multinacionais ou representantes de etiquetas estrangeiras no país, para as grandes gravadoras brasileiras era muito fácil lançar um disco já gravado no exterior do que arcar com as despesas da gravação de um disco no Brasil. E isso não só porque os discos estrangeiros já vinham com seus custos de gravação cobertos pelas vendas realizadas no mercado de origem - o que fazia diminuir o número de unidades que precisavam ser vendidas para a realização do lucro, fazendo consequentemente diminuir o risco próprio do investimento. A facilidade encontrada pelas grandes gravadoras decorria também de que, embora sempre tenha havido forte taxação sobre a importação de gravações, sempre foi igualmente possivel fazê-las entrar no país como se fossem "amostras sem valor comercial" - prática essa que, por outro lado, embora sempre tenha sido proibida por lei, sempre foi também tolerada pelas autoridades competentes (2009, p. 62).

Em síntese, artistas e gravações estrangeiras compõem o foco primordial da indústria fonográfica atuante no Brasil nos primeiros anos da 1970, atingindo níveis exorbitantes $^{27}$. Logo em seguida, pode-se dizer, que a partir de meados de 1973, um núcleo de artistas referendados como legítimos representantes da MPB (canção) assumem o protagonismo das gravadoras, consolidando-se como artistas de catálogo (DIAS, 2000, p. 82): aqueles que mantêm contrato seguro por vários anos, com privilégios de estúdio e agregam um valor simbólico de "autenticidade artístico-cultural", além da vendagem propriamente dita. Dessa forma, o estúdio como um espaço da criatividade, jam sessions, improvisos e experimentações instrumentais passou, cada vez mais, a não caber na distribuição logística e administrativa das grandes gravadoras. Isto aponta para o fato de que o jazz brasileiro vai ficando distante, progressivamente, das produções realizadas pelas majors.

Mesmo que o setor fonográfico esteja em ampla expansão desde meados dos anos 1960 e durante todo os anos 1970 (VICENTE, 2014; DIAS, 2000) os caminhos mercadológicos para a música instrumental e para o jazz brasileiro ficaram cada vez mais reduzidos. Dessa forma, as condições fonográficas impostas ao contexto posterior à explosão do sambajazz (expostas também pela única obra de Tenório Jr) realizam um tipo de censura indireta às condições de possibilidade de gravação, lançamento e distribuição do material vinculado ao jazz e a música instrumental no mercado musical brasileiro. Tal conjuntura não se altera a partir de 1976, quando boa parte dos músicos encontra

27 Segundo os índices publicados pela Jornal do Brasil a partir dos dados do caderno semanal Bolsa de Disco - a música estrangeira (matriz gravada fora do Brasil) atinge a marca de $63 \%$ das vendas do mercado carioca no segundo semestre de 1971 , e $84 \%$ no primeiro semestre de 1972 (MORELLI, 2009, p. 63). Os dados destacados por Eduardo Vicente (2014, p. 55) corroboram com a tese de Morelli, sobre uma grande inserção de música estrangeira/internacional entre 1970-1973. 
novas soluções para inserção do seu material na indústria fonográfica, gerando um elo inerente entre o jazz brasileiro (instrumental) e a produção musical "independente" que emergia no sudeste do país em torno de iniciativas autônomas dos próprios músicos e/ou pelo selos e empreendimentos de pequeno porte como o Lira Paulistana Instrumental (RUIZ, 2020) e o Som da Gente (MULLER, 2005), dentre outros. Também é muito importante lembrar: justamente neste ínterim (1968-1976) ocorre a consagração dos festivais da canção, tendo como marco inicial os FICs (1966-1972), empreitadas que fortaleceram amplamente a tendência da música cantada no mercado de música nacional.

Bahiana (1979) reflete sobre os motivos que levaram o jazz/instrumental brasileiro a um período de poucas oportunidades no mercado brasileiro nos primeiros anos da década de 1970. Além do desinteresse logístico das gravadoras, Bahiana ressalta a falta de público. Ou nas palavras da autora: "o jejum forçado imposto às plateias" e uma "enorme apatia do público" (1979, p. 79). Ela também aponta para o ciclo vicioso dos instrumentistas enquanto acompanhantes de intérpretes (conforme comentado ao longo do trabalho), destacando, também: "uma atrofia dos próprios criadores em potencial, depois de anos acompanhando cantores, fechados em ciclos restritos e autofágicos, isolados e queixosos, desanimados inclusive pelos próprios problemas imediatos, profissionais, da classe" (1979, p. 79-80).

Dessa forma, é muito importante demonstrar que, ao contrário do que afirma Frederico de Oliveira, a partir do assassinato de Tenório Jr., o ano de 1976 não é marcado pelo fim absoluto da música instrumental e do jazz brasileiro, mas, ao contrário, justamente pela retomada do seu crescimento em território nacional, com diversas iniciativas favorecendo essas propostas (RUIZ, 2017, p. 24-51). Interessante reforçar novamente que o boom do sambajazz faz parte de um momento muito particular de nossa história musical, no qual conjuntos como o Tamba Trio “[subverteram] o papel dos grupos instrumentais da época, que até então se limitavam a acompanhar os cantores, e os trouxe para o centro das atenções, como na escola bebop" (ALEXANDRE, 2009, p. 52). Ou seja, as transformações e o apagamento no lugar do instrumentista e de sua música nas décadas de 1960 e 1970 se relacionam a múltiplos elementos que se conectam numa cadeia assimétrica de construção simbólica, conduzidos pelo devir de processos históricos multifacetados - muitos deles relacionados aos aspectos produtivos da indústria fonográfica - mas, não condizem com o teor conspiratório e ressentido do autor de Crime contra Tenório.

Ademais, conforme afirma Bahiana, a partir de 1976 ocorreu uma "modificação no comportamento do mercado" ocasionando "não exatamente um boom de música instrumental", mas possibilitando o surgimento de novos nomes nesse cenário e, dessa forma, "aumentando o leque de opções" (1979, p. 80). Por extrapolar os limites deste estudo, o reavivamento do cenário jazzístico após 1976 ficará a cargo de outros trabalhos ${ }^{28}$. 


\section{Considerações investigativas: resoluções e diagnósticos}

Convém um último comentário crítico: estando em jogo um tipo de memória que correlaciona os artistas com a ditadura, vale lembrar que não apenas certa canção se sobressaiu por se autointitular "de protesto", como boa parte dos artistas da MPB conquistaram prestígio pela experiência do exílio ou da perseguição política. A memória da resistência, nesse sentido, irrompe como aspecto que confere mais "qualidade" e "valor" a determinados artistas e às suas composições (ALONSO, 2011; RIBEIRO JÚNIOR, 2018). Para disputar à altura com esse valor, a figura de Tenório é ativada por determinados defensores do instrumental e por agentes que acreditam terem sido vitimados pelas transformações no mercado musical dos anos 60, numa operação que se vale, por sua vez, da memória do mártir, a fim de reaver um prestígio do jazz/instrumental brasileiro de outrora.

Dessa maneira, a metáfora idealizada por Oliveira (1997; 2017), e referendada por outros autores, teria um interesse estético-ideológico, vislumbrando na trama política que engoliu Tenório (esculpido como ingênua personagem esmagada por poderes inimagináveis) o elemento memorialístico necessário para ascender em valor e acessar esse lugar privilegiado tão caro ao panteão da MPB. Eis que sob pretexto da busca pela "verdade" do que ocorreu ao pianista, entre os compassos e os descompassos da memória, a tentativa de vender a imagem dos instrumentistas como injustiçados, recuperando, através da relativização do valor dos consagrados/estabelecidos, a preponderância perdida.

Não se pode negar, conforme demonstramos no trabalho, que o mercado fonográfico realmente passou por mudanças entre os anos 60 e 70, impactando fortemente a música instrumental e o jazz brasileiro. E nesse aspecto, discordamos dos autores que negam que o campo jazzístico nacional tenha passado por um processo de ressignificação e de reposicionamento no mercado, pois, como discutimos, se até meados dos anos 1960 a separação entre música cantada e instrumental ainda era pequena, apesar das problemáticas enfrentadas pelos instrumentistas focados no viés sem letra, tal divisão vai, progressivamente, afastando-se em polos opostos durante os anos 1970. Narrativas que omitem esse fenômeno incorrem numa não problematização da história oficial da música popular brasileira em tempos de ditadura e acabam resguardando acriticamente a memória da MPB.

Por outro lado, diferente da interpretação de França (2015), entendemos que a versão de Oliveira $(1997 ; 2017)$ também não é desinteressada, nem atende apenas a interesses estéticos. O que se evidencia no discurso do autor, além do embate de forças com as versões oficiais sobre o passado da MPB, é a tentativa de difundir também uma visão revisionista da história da ditadura. Justamente por isso optamos pelo uso das duas edições de sua obra, pois embora desde a primeira versão tenhamos notado uma postura política ambígua em relação ao regime e às esquerdas, na segunda edição percebemos uma guinada mais evidente do autor ao conservadorismo; tendência ideológica que defende atualmente. Tal detalhe faz toda a diferença no diagnóstico crítico do autor, que por vezes relativiza a expressão "ditadura", aproveitando a presente conjuntura para proliferar a equivocada noção de uma "ditabranda". 
Analisamos que, por evocar a brutalidade cometida contra Tenório como representação das injustiças passadas pela produção instrumental brasileira, Oliveira (2017) acaba caindo em contradição quando tenta relativizar o autoritarismo do regime, modelo de governo cuja proposta cultural e modus operandi político seria peça fundamental nesse quebra-cabeças conspiratório por ele denunciado. Temos, assim, um saldo de contradições, dissonâncias e disputas de poder motivadas pela ambígua relação entre a canção popular e a música instrumental, iniciada em fins de 1960 e início de 1970.

Esclarecemos que como pesquisadores dispostos a "escovar a História a contrapelo", reconhecemos como um ganho historiográfico a obra Um crime contra Tenório, no sentido de ser uma das poucas escritas por um instrumentista, indo além do teor biográfico de livros como Memórias do baterista canhoto de Romir Andrade e Solo de César Camargo Mariano. Apesar do tom muitas vezes romanceado e exagerado e de opiniões moralistas, a obra oferece um ponto de vista alternativo quanto à formação da MPB, revisitando acontecimentos exaustivamente trabalhados pela historiografia, mas se deslocando de certos consensos. Mister reconhecer também o louvável esforço no levantamento e organização de informações sobre o caso Tenório Jr., tendo como um de seus objetivos "resgatar a memória de um instrumentista competente, para não deixá-la soterrada na sordidez dos porões do terrorismo de Estado", como bem pontua o jornalista José Nêumanne Pinto em texto de contracapa.

Contudo, ao traçar uma fase heroica da música instrumental brasileira (sendo esta devedora de uma tradição musical que se remeteria aos tempos de Ary Barroso, Pixinguinha etc.) e uma fase de vertiginosa decadência da música brasileira (deslocamento do conceito de canção, subdimensionamento do instrumental, padronização comercial da "baixa qualidade" musical), entendemos que a visão trágica de Frederico Mendonça se ancora numa mentalidade evolucionista, com um pé na ideia de "linha evolutiva" da música popular. Nessa lógica, conceber que a música instrumental, em dado momento, recebeu um golpe mortal, que interrompeu definitivamente um longo fluxo de inovações, significa que haveria um devir evolutivo para o jazz brasileiro a partir da chamada MPM. Nesse esquema idealizado, o instrumental manteria ou até superaria o prestígio cultural e simbólico da bossa nova, gerando, assim, novas escolas para o jazz nacional, sendo estas diretamente relacionadas ao sucesso comercial do sambajazz. Sem renunciar a esse paradigma evolucionista, mas muito mais ligados à modernidade bossanovista/emepebista (desconsiderando, acrescente-se, seus processos de seleção e exclusão), as vozes contrárias, a exemplo de Falcão (2017), não cotejaram os problemas específicos que atingiram os instrumentistas nos anos 60 , recaindo numa visão algo simplista sobre os acontecimentos.

Demonstramos que longe das manipulações da memória e dos discursos alheios, a vida de Tenório nos dá pistas, até certo ponto, sobre a situação do instrumental brasileiro. Enquanto representação, porém, ultrapassa o objeto representado, pois ambos seguem rumos históricos distintos. O pianista não pôde ser absorvido pelo contexto de renovação do jazz brasileiro (a exemplo dos movimentos Lira Paulistana e Black Rio), restando, por um lado, especulações e insinuações acerca de uma música instrumental que - tão vigorosa 
quanto à imagem de um Tenório vivo, exitoso; glorificado/patrimonializado pelas instâncias de consagração - elevaria o samba ao status de música potencialmente improvisativa, à altura e, talvez, até superior ao jazz, como propunha certo discurso internacional-popular na época (RIBEIRO JÚNIOR, 2018). Em contrapartida, as especificidades que envolvem a vida do músico (assassinado em outro país; corpo jamais encontrado; forma hesitante de tratamento desses traumas na memória brasileira e indisposição do Estado em promover discussões públicas mais substanciais sobre a ditadura) podem ter interferido nas inconsistências no trato com a sua memória: problema mobilizado e instrumentalizado na projeção de um jazz brasileiro igualmente "moribundo".

Se essas inconsistências têm relação com uma suposta desvalorização do jazz no Brasil? Difícil responder nestes termos. Tenório não viveu para ser esquecido. Sua morte abre e fecha múltiplas possibilidades. Além disso, é preciso reconhecer que tem havido esforços para fazer com que sua memória ecoe. E embora saibamos que tenha se fabricado um lugar específico para o jazz brasileiro (com drástico impacto em carreiras ligadas ao sambajazz; e com circuitos, nicho, mediadores, impacto comercial e significações próprias), dentro do qual o alcance das memórias se projeta de maneira desigual em comparação a dos artistas vinculados à canção popular, não se pode reduzir essa discussão à trajetória de uma só pessoa ou de uma escola do instrumental brasileiro. Isto é, ainda que o caso de Tenório e a situação do sambajazz possam ser compreendidos como exemplos históricos bastante elucidativos dessas questões do campo do jazz nacional, é preciso investir em outras investigações, analisar outros casos... lançar o olhar aquém e além das cenas do crime.

\section{Referências}

ALBIN, R. C. Dicionário Houaiss Ilustrado da Música Popular Brasileira. Instituto Cultural Cravo Albin. Rio de Janeiro: Paracatu, 2006.

ALEXANDRE, R. Nem vem que não tem: a vida e o veneno de Wilson Simonal. São Paulo, Globo, 2009.

ALONSO, G. Quem não tem swing morre com a boca cheia de formiga: Wilson Simonal e os limites de uma memória tropical. Rio de Janeiro: Record, 2011.

BAHIANA, A. M. Música instrumental: o caminho da improvisação à brasileira. In: BAHIANA, A. M. M. et. al. Anos 70: Música Popular. Rio de Janeiro: Europa Empresa Gráfica, 1979/1980, p. 76-89.

Almanaque dos anos 70. Rio de Janeiro, Ediouro, 2006. 
BARROS, F. L. Do Calypso ao chá-chá-chá: músicos em São Paulo na década de 60. 1. Ed. Nova Ilusão Edições, São Paulo, 2012.

BASTOS, M.B; PIEDADE, A.T.C. O desenvolvimento histórico da "música instrumental": o jazz brasileiro. Anais do XVI Congresso da Associação Nacional de Pesquisa e Pósgraduação em Música (ANPPOM) Brasília - 2006, p. 931-936.

BOURDIEU, P. O Poder Simbólico. 5 ed. Rio de Janeiro: Bertrand Brasil. 2002.

A ilusão biográfica. In: Razões práticas: sobre a teoria da ação. 11 ed. São Paulo: Papirus, 2011, 74-82.

CALADO, C. Tropicália: a história de uma revolução musical. SP. Editora 34, 1997.

CAMPOS, D. R. Os trios brasileiros da década de 1960: aspectos da condução do contrabaixo. 2014. 210 f. Dissertação (Mestrado em Música) - Instituto de Artes, Universidade Estadual de Campinas, Campinas, 2014.

CASTRO, R. Tempestade de ritmos: jazz e música popular no século XX. São Paulo: Companhia das Letras, 2007.

A onda que se ergueu no mar: novíssimos mergulhos na Bossa Nova. Companhia das Letras, $2^{a}$ ed. São Paulo, 2017.

COMISSÃO NACIONAL DA VERDADE (relatório). Capítulo 6: Conexões internacionais: a aliança repressiva no cone sul e a operação condor. Vol. 01, Brasília, dezembro de 2014a.

Capítulo 09: A resistência da sociedade civil às graves violações dos direitos humanos Vol. 01, Brasília, dezembro de 2014b.

DIAS, M. T. Os donos da voz: indústria fonográfica e mundialização da Cultura. São Paulo: Boitempo, 2000.

FALCÃO, A. Contos na era das canções e outros escritos. Cepe editora, Pernambuco, 2017.

FENERICK, J. A. Façanha às próprias custas: a produção musical da vanguarda paulista (1979-2000). São Paulo: Annablume, 2007

FIUZA, A. F. Repressão no Brasil e na Argentina: o caso Tenório Jr. Anais do IV Congresso Brasileiro de Hispanistas, Rio de Janeiro: UERJ/CNPq/ABH, v. 03, 2006, p. 526-532. 
FRANÇA, G. M. I. Sambajazz em movimento: o percurso dos músicos no Rio de Janeiro, entre fins dos anos 1950 e início dos anos 1960. Tese (Doutorado em Ciências Sociais). 353 f. Programa de Pós-Graduação da Pontifícia Universidade Católica do Rio de Janeiro, Departamento de Ciências Sociais, 2015.

GINZBURG, C. Micro-história: duas ou três coisas que sei a respeito. In: [2006] O fio e os rastros - verdadeiro, falso, fictício. São Paulo: Cia. das Letras, 2007, p. 249 - 279.

GOMES, M. S. Samba-Jazz aquém e além da Bossa Nova: três arranjos para Céu e Mar de Johnny Alf. Tese (Doutorado em Música). Instituto de Artes. Universidade Estadual de Campinas, Campinas, 2010.

HALBWACHS, M. A Memória coletiva. Trad. de Laurent Léon Schaffter. São Paulo: Vértice/Revista dos Tribunais, 1990.

LEVY, D. W. O "Brazilian Jazz" na década de 1980 no eixo Rio-São Paulo. Dissertação (Mestrado em Música), Universidade Federal do Estado do Rio de Janeiro, Rio de Janeiro, 2016. $147 \mathrm{f}$.

MAYRINK, G. Mi Buenas Aires Maldito: Homem errado, no lugar errado, o pianista Tenório Jr. ganhou aplausos no palco e depois sumiu nas trevas da ditadura argentina. Revista Época, Editora Globo, São Paulo, 28/07/2010. Disponível em: Brasil - EDT MATERIA IMPRIMIR - Mi Buenos Aires maldito (globo.com).

MONGIOVI, A. G. Num doce balanço: composições, identidade e tópicas do jazz brasileiro. Tese (Doutorado em Música), Departamento de comunicação e arte, Universidade de Aveiro, Aveiro, 2017.

MORAES, V. de. Para uma menina com uma flor. São Paulo: Cia das Letras, 2009.

MOREIRA, M. B. C. Um coração futurista: desconstrução construtiva nos processos composicionais de Egberto Gismonti na década de 1970. Tese (Doutorado em Música) - Instituto de Artes, Universidade Estadual de Campinas, Campinas, 2016.

MORELLI, R. de C. L. Indústria fonográfica: um estudo antropológico. Campinas: Ed. UNICAMP, 2009.

MULLER, D. G. M. Música instrumental e indústria fonográfica no Brasil: a experiência do selo Som da Gente. 201 f. Dissertação (Mestrado em Música) - Instituto de Artes, Universidade Estadual de Campinas, Campinas, 2005. 
NAPOLITANO, M. Seguindo a canção: engajamento político e indústria cultural na MPB (1959-1969). São Paulo: Annablume, 2001.

OLIVEIRA, C.F.S de. A MPB (Música Popular Britânica) que veio de Londres: uma discussão sobre Música Brasileira e Mundialização. 2007. (Apresentação de Trabalho/ Comunicação).

OLIVEIRA, F. M. de. O crime contra Tenório: saga e martírio de um gênio do piano brasileiro. $1^{\underline{a}}$ ed. Atenas Editorial, Minas Gerais, 1997.

O crime contra Tenório: saga e martírio de um gênio do piano brasileiro.

$2^{a}$ ed. Cria Editora, Minas Gerais, 2017.

ORTIZ, R. A moderna tradição brasileira: cultura brasileira e indústria cultural. São Paulo: Brasiliense, 1988.

POLLAK, M. Memória, esquecimento, silêncio. Estudos Históricos, Rio de Janeiro, vol. 02, n. 03, 1989.

Memória e identidade social. Estudos Históricos, Rio de Janeiro. vol. 05, n. 10, 1992, p. 200-212.

QUADRAT, S. V. Operação Condor: o "Mercosul" do terror. Estudos Ibero-Americanos. PUC-RS, v. XXVIII, n. 01, p. 167-182, junho de 2002.

RIBEIRO JÚNIOR, A. C. A. Polifonia de vozes e produção de sentidos na imprensa: um estudo sobre os discursos da crítica musical brasileira acerca da influência do jazz na MPB 1962-1970. 233 f. Dissertação (Mestrado) - Programa de Pós-graduação em Cultura e Sociedade, Universidade Federal do Maranhão, 2018.

ROSAS, P. Zorobabel. 1aㅗ ed. São Paulo: Editora Livrus, 2015.

RUIZ, R. B. Atitude muda: o Grupo Um, a produção musical independente e o Lira Paulistana (1976 - 1984): Speechless attitude: Grupo Um, the musical independent production and the Lira Paulistana (1976 - 1984). Revista Caminhos da História, v. 25, n. 2, p. 136-162, 1 jul. 2020.

Marcha sobre a cidade: Diálogos entre jazz e rock no Brasil setentista. In: José Adriano Fenerick (Org.). Nas Trilhas do Rock: contracultura e vanguarda. Curitiba: Ed. Appris. 2021a. 
Mobile/Stabile: O Grupo Um no Festival de Jazz São Paulo - Montreux

(1978). Fênix - Revista De História E Estudos Culturais, 18(1), 385-406, 28 jun. 2021 b.

"Procura-se Mecenas": Música independente e indústria fonográfica na

trajetória artística do Grupo Um (1976-1984). 215 f. Dissertação (Mestrado em História)

- Faculdade de Ciências Humanas e Sociais, Universidade Estadual Paulista "Júlio de Mesquita Filho", Franca, 2017.

SARAIVA, J. M. A invenção do sambajazz: discursos sobre a cena musical de Copacabana no final dos anos 1950 e início dos anos 1960. Dissertação (Mestrado em História) PUC, Rio de Janeiro, 2007.

SOUZA NETO, M. J. de. Ordem dos Músicos do Brasil. Memória e Verdade: a herança da ditadura militar. 50 anos de repressão. In: Anais do III Encontro Internacional de Direitos Culturais. "Direitos Culturais, Memória e Verdade", Universidade Federal de Fortaleza, Ceará, 7-11, outubro de 2014, s/p.

VALLEJOS, C. A história oficial. Entrevista concedida a Maurício Dias. Revista Senhor: política, economia e negócios. Editora Três, Rio de Janeiro, no 270, p. 44-51, 20/05/1986.

VICENTE, E. Da vitrola ao ipod: uma história da indústria fonográfica no Brasil. São Paulo, Alameda, 2014. 